\section{HIV/AIDS coinfection with the hepatitis B and C viruses in Brazil}

\author{
Coinfecção HIV/AIDS com hepatites virais B e C \\ no Brasil
}

\section{Coinfección VIH/SIDA con hepatitis viral B y C en Brasil}

1 Ministério da Saúde, Brasília, Brasil.

2 Faculdade de Ciências da Saúde, Universidade de Brasília, Brasília, Brasil.

3 Instituto de Matemática, Universidade Federal da Bahia, Salvador, Brasil.

Correspondence S. B. Oliveira Ministério da Saúde. SAF SUL 2 Lote 4/5, Ed Premium, Brasilia, $D F$ 70070-600, Brasil.

silbaroli@yahoo.com.br

\begin{abstract}
The aim of this study is to estimate the prevalence of HIV/HBV and HIV/HCV coinfections among AIDS cases reported in Brazil, and to describe the epidemiological profile of these cases. Coinfection was identified through probabilistic record linkage of the data of all patients carrying the HIV virus recorded as AIDS patients and of those patients reported as carriers of hepatitis $B$ or $C$ virus in various databases from the Brazilian Ministry of Health from 1999 to 2010. In this period 370,672 AIDS cases were reported, of which 3,724 were HIVIHBV coinfections. Women are less likely to become coinfected than men and the chance of coinfection increases with age. This study allowed an important evaluation of HBVIHIV and HCVIHIV coinfections in Brazil using information obtained via merging secondary databases from the Ministry of Health, without conducting seroprevalence research. The findings of this study might be important for planning activities of the Brazilian epidemiologic surveillance agencies.
\end{abstract}

Hepatitis Viruses; HIV; Acquired Immunodeficiency Syndrome; Coinfection
Silvano Barbosa de Oliveira 1

Edgar Merchán-Hamann 2

Leila Denise Alves Ferreira Amorim 3

\section{Resumo}

O presente estudo tem como objetivo estimar a prevalência de coinfecção HIVIHBV e HIVI HCV entre os casos de AIDS notificados no Brasil e descrever o perfil epidemiológico dos casos coinfectados. A coinfecção foi identificada pelo relacionamento probabilístico entre todos os pacientes com HIV notificados como casos de AIDS, e os casos de hepatites virais $B$ e $C$ em diferentes bases de dados do Ministério da Saúde, no período de 1999 a 2010. Nesse período, 370.672 casos de AIDS foram notificados, sendo 3.724 coinfectados com HBV e 5.932 com HCV. As mulheres têm menos chance de coinfecção que os homens. A chance de coinfecção aumenta com a idade, sendo três vezes maior entre os coinfectados com HBV com 45 anos ou mais. Este estudo permitiu uma importante avaliação dos perfis de coinfecção por HBV/HIV e HCVIHIV no Brasil pela utilização de dados secundários do Ministério da Saúde. Os achados deste estudo podem ser úteis para planejar ações de vigilância epidemiológica no Brasil.

Vírus da Hepatite; HIV; Síndrome de Imunodeficiência Adquirida; Coinfecção 


\section{Introduction}

HIV infection has a pandemic aspect and is extremely severe, making it one of the most important current health problems 1,2,3. Hepatitis viruses cause liver infections of different types, depending on the etiologic agent, the most common being the type A (HAV), B (HBV), and $\mathrm{C}$ (HCV) viruses 2,4,5. The importance of viral hepatitis in public health is well known due to the large number of infected individuals and the complications caused by the infection ${ }^{2}$.

Hepatitis B and C viruses and the HIV virus share the most important forms of transmission, in particular sexual, by blood, and vertical (mother to child) transmission. Infections by these viruses present a dynamic interaction, amplifying each other and leading to greater morbidity and mortality in coinfected patients. HIV-infected individuals who also develop acute hepatitis B are 5 to 6 times more likely to become chronic carriers of $\mathrm{HBV}$ and are also at greater risk of developing severe liver diseases that may result in death 6,7 .

The HIV virus accelerates the evolution of liver diseases caused by hepatitis B and C, especially in patients with greater immune deficiencies. Thus, coinfected patients suffer more severe consequences than mono-infected patients. For example, HIV/HCV coinfected individuals show a faster progression of fibrosis, the risk of vertical transmission increases from $6 \%$ to $20 \%$, and the risk of sexual transmission increases by $3 \%$. Among HIV/HBV coinfected individuals, the infection is more severe and causes more aggressive cases of cirrhosis and liver cancer. In this situation, the risk of cirrhosis increases 4.2-fold, mortality also increases, and, in some cases, the hepatitis B virus can be reactivated 8,9,10.

According to Soriano et al. 9, the prevalence of patients coinfected with HIV/AIDS and hepatitis $B$ and $C$ varies worldwide because of the different forms of transmission. Clinical studies conducted in Brazil show that, among HIV/AIDSinfected individuals, about $6 \%$ were positive for HBsAg, while anti-HCV positivity varies from 5 to $18 \% 9,10$.

The main purpose of this study is to estimate the prevalence of HIV/HBV and HIV/HCV coinfections among notifiable AIDS cases in Brazil, as well as to describe the epidemiological profile of these cases.

\section{Material and methods}

This study examined the data of all HIV-positive patients who were reported as AIDS patients in Brazil and who met the criteria that define an AIDS case. Data was obtained from various sources, including the Notifiable Diseases Information System (SINAN), the Laboratory Tests Control System (SISCEL), and Medication Logistics Control System (SICLOM), which are databases of the Brazilian Ministry of Health.

AIDS cases in children and adults from 1999 to 2010 were obtained from the SINAN database. From the SISCEL and SICLOM databases, the patients' records during the period of 2000 to 2010 that met the following criteria were selected: (i) TCD4+ cell count less than expected for the age and detectable viral load; (ii) TCD4+ cell count less than expected for the age and use of medication registered in SICLOM; (iii) TCD4+ cell count less than expected for the age, detectable viral load, and use of medication 11 .

Cases of viral hepatitis B and C were obtained from SINAN's notifications for the period 1999 to 2010. For hepatitis B, cases that presented at least one of the following serum markers were considered: HBsAg, Anti-HBc IgM, or HBeAg; and for hepatitis $\mathrm{C}$, those with the following markers were considered: anti-HCV and HCV-RNA 2

Linkage between AIDS and hepatitis B and $\mathrm{C}$ cases were used to estimate the prevalence of $\mathrm{HIV} / \mathrm{HBV}$ and HIV/HCV coinfection.

The database initially contained 371,631 AIDS cases between 1999 and 2010. 11 records that did not contain information about the city of residence, 901 records that did not contain the birth date, and 47 with inconsistent birth date were excluded, bringing the final total to 370,672 AIDS cases (99.7\%).

The variable "category of exposure" (related to AIDS) used in the analysis was extracted from the SINAN database. The categories "heterosexual", "homosexual", and "bisexual" were regrouped under the category "sexual transmission", while the categories "transfusion" and "hemophiliac" were regrouped under "blood transmission".

A logistic regression model was used to estimate the chance of patients being coinfected depending on certain socio-demographic variables. The measure of association presented is the odds ratio (OR), with corresponding 95\% confidence intervals $(95 \% \mathrm{CI})$. Separate analyses were conducted for HIV/HBV and HIV/HCV coinfections. Analyses were conducted using Stata v.12 software (Stata Corp., College Station, USA).

\section{Results}

In Brazil, 370,672 AIDS cases were reported in the period of 1999 to $2010,86.3 \%$ of which were registered in the SINAN database and $13.7 \%$ in the SISCEL and SICLOM databases. Globally, 50.7\% 
of these notifications came from the Southeast region, followed by the South $(22.9 \%)$, Northeast (14.5\%), Central (6.2\%), and North (5.7\%). AIDS patients are, on average, 43 years old (median = 43 years), and $24.2 \%$ of them have 4 to 7 years of schooling. Most of these patients are male (61.0\%), white $(35.9 \%)$, and fall into the category of sexual exposure (64.9\%).

Record linkages of the AIDS and viral hepatitis $\mathrm{B}$ and $\mathrm{C}$ databases allowed for detection of 3,724 HIV/HBV-coinfected and 5,932 HIV/HCVcoinfected individuals. Thus, we observed that $1 \%$ and $1.6 \%$, respectively, of the notifiable AIDS cases presented HBV/HIV and HCV/HIV coinfections during the period 1999 to 2010.

Table 1 shows that HIV/AIDS-infected individuals (coinfected and non-coinfected) are mostly males. It is also notable that $81.0 \%$ and $73.7 \%$, respectively, of HBV and HCV-coinfected individuals are male. Thus, women are less likely to become coinfected than men (HBV/HIV: OR = 0.39, 95\%CI: 0.35-0.42; HCV/HIV: OR $=0.78$, 95\%CI: $0.73-0.83$ ). The chance of coinfection increases with age; it is three times higher in older individuals coinfected with HBV than patients aged 24 and younger; among those coinfected with HCV, the chance can be up to 12 times higher.

The geographical distribution of individuals coinfected with hepatitis B shows that the Southeast region has $57.1 \%$ of all notifiable cases, followed by the South (23.2\%), and the Central (7.7\%) regions (Figure 1). Among those coinfected with hepatitis C, the Southeast region has $65.9 \%$ of all notifiable cases, also followed by the South (28.5\%), as showed in Figure 1. According to dis- tribution by race/color, most patients are white: $43.8 \%$ and $48.2 \%$, respectively, of HBV and HCV coinfected individuals. With regard to schooling, most individuals coinfected with HBV have had at least 8 years of formal education $(32.9 \%)$ and, among those coinfected with $\mathrm{HCV}, 34.6 \%$ have had 4-7 years (Table 1).

The logistic regression model shows that, in relation to schooling, patients with at least 8 years of formal education are $26 \%$ more likely to have HIV/HBV coinfection when compared to patients with no schooling. Among the HIV/HCV coinfected patients, the chance of coinfection increases with more years of schooling - up to twice as high (Table 1).

Most cases fell into the category of exposure to AIDS through sexual activity (homosexual, bisexual, and heterosexual), followed by injecting drug users (IDU). The percentage of blood exposure is below $1 \%$ for all coinfected individuals (Table 1). However, the chance for coinfections increases 2- to 6-fold for HBV and HCV, respectively, when the IDU category is compared with sexual exposure.

\section{Discussion}

For this study, we used positive symptomatic cases of hepatitis B and C recorded in the SINAN database. It has been suggested that the number of viral hepatitis cases in the official databases are underestimated 6,7,12. Besides that, we understand that the undernotification of viral hepatitis, which can also be related to limited access to serologic diagnosis of HCV and HBV, may fluctuate

Figure 1

Distribution of coinfected HIV/AIDS-HBV and HIV/AIDS-HCV cases, by region of residence. Brazil, 1999-2010.

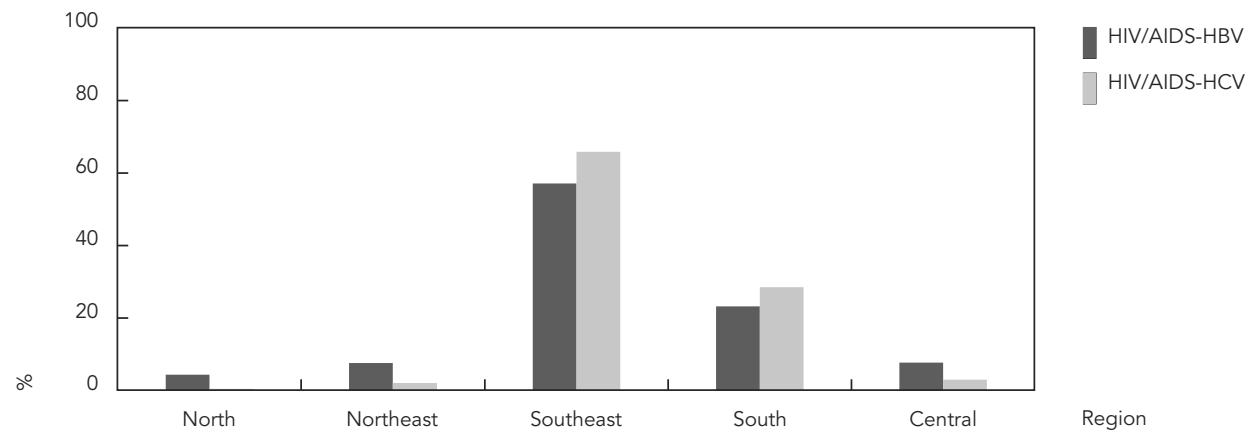


Table 1

Distribution of HIV/AIDS cases mono and coinfected with HBV and HCV, by socio-demographic variables. Brazil, 1999 to 2010.

\begin{tabular}{|c|c|c|c|c|c|c|c|c|c|c|}
\hline \multirow[t]{2}{*}{ Variables } & \multicolumn{2}{|c|}{ Not coinfected } & \multicolumn{2}{|c|}{$\begin{array}{c}\text { Coinfected with } \\
\text { HBV }\end{array}$} & \multirow[t]{2}{*}{$\mathrm{OR}_{\text {adjusted }}$} & \multirow[t]{2}{*}{$95 \% \mathrm{Cl}$} & \multicolumn{2}{|c|}{ Coinfected with HCV } & \multirow[t]{2}{*}{$\mathrm{OR}_{\text {adjusted }}$} & \multirow[t]{2}{*}{$95 \% \mathrm{Cl}$} \\
\hline & $\mathrm{n}$ & $\%$ & $\mathrm{n}$ & $\%$ & & & $\mathrm{n}$ & $\%$ & & \\
\hline Total & 361,325 & 100.0 & 3,724 & 100.0 & & & 5,932 & 100.0 & & \\
\hline \multicolumn{11}{|l|}{ Age group (years) } \\
\hline$<25$ & 17,202 & 4.8 & 33 & 0.9 & 1.00 & & 16 & 0.2 & 1.00 & \\
\hline $25-34$ & 62,149 & 17.2 & 595 & 16.0 & 2.91 & $1.94-4.34$ & 318 & 5.4 & 3.45 & $1.90-6.28$ \\
\hline $35-44$ & 124,675 & 34.5 & 1,413 & 37.9 & 3.11 & $2.09-4.63$ & 2,290 & 38.6 & 9.80 & $5.43-17.68$ \\
\hline 45 or older & 157,299 & 43.5 & 1,683 & 45.2 & 2.92 & $1.96-4.35$ & 3,308 & 55.8 & 12.11 & $6.72-21.84$ \\
\hline \multicolumn{11}{|l|}{ Gender } \\
\hline Male & 219,118 & 60.6 & 3,018 & 81.0 & 1.00 & & 4,369 & 73.7 & 1.00 & \\
\hline Female & 142,188 & 39.4 & 706 & 19.0 & 0.39 & $0.35-0.42$ & 1,563 & 26.3 & 0.78 & $0.73-0.83$ \\
\hline Unknown * & 19 & 0.0 & 0 & - & & & 0 & - & & \\
\hline \multicolumn{11}{|l|}{ Race/Color } \\
\hline White & 128,618 & 35.6 & 1,630 & 43.8 & 1.00 & & 2,862 & 48.2 & 1.00 & \\
\hline Black or mixed & 104,193 & 28.8 & 1,093 & 29.4 & 0.99 & $0.91-1.08$ & 1,345 & 22.7 & 0.89 & $0.84-0.96$ \\
\hline Asian or indigenous Indian & 1,522 & 0.4 & 11 & 0.3 & 0.60 & $0.33-1.09$ & 22 & 0.4 & 0.81 & $0.53-1.24$ \\
\hline Unknown * & 126,992 & 35.1 & 990 & 26.6 & 0.79 & $0.72-0.86$ & 1,703 & 28.7 & 0.86 & $0.81-0.92$ \\
\hline \multicolumn{11}{|l|}{ Education (years) } \\
\hline None & 10,238 & 2.8 & 85 & 2.3 & 1.00 & & 92 & 1.6 & 1.00 & \\
\hline $1-3$ & 48,873 & 13.5 & 483 & 13.0 & 1.01 & $0.80-1.28$ & 950 & 16.0 & 1.58 & $1.27-1.96$ \\
\hline $4-7$ & 86,783 & 24.0 & 1,026 & 27.6 & 1.16 & $0.93-1.45$ & 2,055 & 34.6 & 2.08 & $1.68-2.57$ \\
\hline 8 or more & 93,872 & 26.0 & 1,226 & 32.9 & 1.26 & $1.01-1.57$ & 1,711 & 28.8 & 1.96 & $1.59-2.43$ \\
\hline Unknown * & 121,559 & 33.6 & 904 & 24.3 & 1.07 & $0.85-1.34$ & 1,124 & 18.9 & 1.39 & $1.12-1.73$ \\
\hline \multicolumn{11}{|l|}{ Category of transmission } \\
\hline Sexual ** & 235,546 & 65.2 & 2,453 & 65.9 & 1.00 & & 2,914 & 49.1 & 1.00 & \\
\hline IDU & 23,478 & 6.5 & 579 & 15.5 & 1.79 & $1.62-1.96$ & 2,259 & 38.1 & 6.37 & $6.00-6.77$ \\
\hline 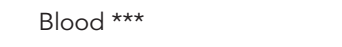 & 389 & 0.1 & 8 & 0.2 & 1.63 & $0.81-3.29$ & 33 & 0.6 & 6.59 & 4.58-9.48 \\
\hline Vertical transmission & 8,338 & 2.3 & 11 & 0.3 & 0.41 & $0.21-0.80$ & 9 & 0.2 & 0.86 & $0.39-1.90$ \\
\hline Unknown * & 93,574 & 25.9 & 673 & 18.1 & 0.74 & $0.67-0.82$ & 717 & 12.1 & 0.78 & $0.72-0.86$ \\
\hline
\end{tabular}

HBV: hepatitis B virus; HCV: hepatitis C virus; IDU: injecting drug users.

Source: Ministry of Health, Sanitary Surveillance Agency, Department of STDs, AIDS and Viral Hepatitis.

* Not available in the datasets;

** Sexual: homosexual, bisexual, and heterosexual;

*** Blood: hemophiliac and transfusion.

between regions of Brazil. Therefore, comparisons of stratified data estimated by region might be problematic and biased.

A potential weakness of using information from official databases is related to its accuracy (misclassification) and potential under-notification, which might introduce outcome misclassification (coinfection identification), making estimates of measures of effect (for instance, odds ratios) prone to bias. However, there is no evidence that the linkage procedure or that the case under-notification processes are not equal according to exposure variables, such as gen- der, age group, race, education and category of transmission, satisfying the criteria for the interpretation of the results presented in Table 1. Nevertheless, this study permitted an important evaluation of HBV/HIV and HCV/HIV coinfections in Brazil using information obtained via merging secondary databases from the Brazilian Ministry of Health, without the need to conduct seroprevalence research. Furthermore, it allowed for a description of the epidemiologic profile of individuals coinfected with HBV/HIV and HVC/ HIV in recent years in Brazil, as well as the identification of potential risk factors associated with 
these coinfections. In our study, coinfection prevalence is estimated considering all notifiable and available HIV cases from the Brazilian Ministry of Health's official databases. In order to reduce probability of undernotification, we considered information from different sources (SINAN, SISCEL, SICLOM). It is also important to highlight that notifiable HIV/AIDS cases in Brazil receive medicine for treatment free of charge, which may contribute to improved data quality.

Even though the estimates of coinfections may be underestimated, our study has corroborated many results from the literature $1,3,4,13$. We observe that the prevalence of HIV/AIDS in the population is greater among men than women with approximately two infected men for every woman. Similar results were found in this study in relation to hepatitis $\mathrm{B}$ and $\mathrm{C}$ infections, helping to explain why more than $80 \%$ of coinfected individuals are male 1,3,4,13. The principal source of infection by hepatitis B and HIV is sexual, which is also observed in coinfected patients, especially men who have sex with men, a category that corresponds to $32 \%$ of all coinfections among males. The main form of hepatitis $C$ transmission is contact with contaminated blood, and this mechanism is also one of the main forms of HIV transmission 4,7,8,10. This explains the significant presence of drug users among the coinfected individuals (38.1\%).

The findings of this study might be useful for planning activities of the Brazilian epidemiologic surveillance agencies, as well as to guide prevalence and incidence studies to obtain more detailed data to improve understanding of the HBV/HIV and HCV/HIV coinfections.

\section{Resumen}

Estimar la prevalencia de las coinfecciones VIH/VHB y VIH/VHC entre los casos de SIDA notificados en Brasil $y$ describir el perfil epidemiológico de las coinfecciones. Los casos de coinfección se identificaron por el método de conexión probabilística entre los pacientes con VIH notificados como SIDA y los casos de hepatitis B y C en los diversos sistemas de información del Ministerio de la Salud entre 1999 y 2010. Entre 1999 y 2010, 370.672 casos de SIDA fueron notificados, estos 3724 coinfectados con VHB y 5932 con VHC. Las mujeres son menos propensas a ser co-infectadas que los hombres. $L a$ oportunidad de coinfección aumenta con la edad. Este estudio proporciona una evaluación importante de los perfiles de la coinfección por VIH/VHB y VHC/VIH en Brasil, a través de la utilización de datos secundarios del Ministerio de Salud. Este estudio sirve para orientar las acciones de vigilancia epidemiológica en Brasil, asi como guiar estudios de prevalencia e incidencia que fomenten una mejor comprensión de la coinfección VIH/ $\mathrm{VHB}$ y VIH/VHC.

Virus de la Hepatitis; VIH; Sindrome de Inmunodeficiencia Adquirida; Coinfección

\section{Contributors}

S. B. Oliveira contributed to the composition of the database, analysis and writing of the article. E. MerchánHamann collaborated on the orientation, discussion, correction of results, critical review and writing of the article. L. D. A. F. Amorim helped in guiding the development and execution of analysis, correction and writing of the article.

\section{Acknowledgements}

To the Department of STIs, AIDS and Viral Hepatitis at the Brazilian Ministry of Health, for providing the databases. To my colleagues working in technical surveillance, information and research at the Department of STIs, AIDS and Viral Hepatitis, especially Dr. Gerson Fernando Pereira Mendes, for his support and assistance in carrying out the work. 


\section{References}

1. Rodrigues-Junior AL, Castilho EA. A epidemia da AIDS no Brasil, 1991-2000: descrição espaço-temporal. Rev Soc Bras Med Trop 2004; 37:312-7.

2. Ministério da Saúde. Guia de vigilância epidemiológica. Brasília: Ministério da Saúde; 2005. (Série A. Normas e Manuais Técnicos).

3. Ministério da Saúde. Prevalências e frequências relativas de doenças sexualmente transmissíveis (DST) em populações selecionadas de seis capitais brasileiras, 2005. Brasília: Ministério da Saúde; 2008. (Série G. Estatística e Informação em Saúde).

4. Braga WSM, Castilho MC, Santos ICV, Moura MAS, Segurado AC. Low prevalence of hepatitis B virus, hepatitis $D$ virus and hepatitis virus among patients with human immunodeficiency virus or acquired immunodeficiency syndrome in the Brazilian Amazon basin. Rev Soc Bras Med Trop 2006; 39:519-22.

5. Fonseca JCF. História natural da hepatite crônica B. Rev Soc Bras Med Trop 2007; 40:672-7.

6. Lopes EPA, Silva AE, Sette Junior H, Guimarães RX, Ferraz ML. Autoantibodies before, during and after administration of recombinant interferon-a for chronic viral hepatitis. Rev Inst Med Trop São Paulo 1995; 37:455-60.

7. Corrêa MCJM, Barone AA, Cavalheiro NP, Tengan FM, Guastini C. Prevalence of hepatitis B and C in the sera of patients with HIV infection in São Paulo, Brasil. Rev Inst Med Trop São Paulo 2000; 42:81-5.
8. Amaral ISA, Almeida ML, Alves FT, Móia LJMP, Conde SRSS. Epidemiologia de pacientes coinfectados HIV/HCV atendidos na Fundação Santa Casa de Misericórdia do Pará. Rev Para Med 2007; 21:15-24.

9. Soriano V, Puoti M, Bonacini M. Care of patients with chronic hepatitis B and HIV coinfection: recommendations from an HIV-HBV international panel. AIDS 2005; 19:221-40.

10. Patel P, Davis S, Tolle M, Mabikwa V, Anabwani G. Prevalence of hepatites B and hepatitis C coinfections in an adult HIV centre population in Gaborone, Botswana. Am J Trop Med Hyg 2011; 85: 390-4.

11. Programa Nacional de DST e AIDS, Secretaria de Vigilância em Saúde, Ministério da Saúde. Critérios de definição de casos de AIDS em adultos e crianças. Brasília: Ministério da Saúde; 2005.

12. Camargo Jr. KR, Coeli CM. Reclink: aplicativo para o relacionamento de bases de dados, implementando o método probabilistic record linkage. Cad Saúde Pública 2000; 16:439-47.

13. Treitinger A, Spada C, Ferreira LA, Neto MS, Reis M, Verdi JC, et al. Hepatitis B and hepatitis C prevalence among blood donors and HIV-1 infected patients in Florianopolis-Brazil. Braz J Infect Dis 2000; 4:192-6.

Submitted on 23/Jan/2013

Final version resubmitted on 25/Jul/2013

Approved on 26/Ago/2013 